\title{
Comparative study of oral iron and intravenous iron sucrose for the treatment of iron deficiency anemia in pregnancy
}

\author{
Apurva Garg*, Manju Agarwal, Uma Shankar, Shrikant Shetty
}

Department of Obstetrics and Gynaecology, Jhalawar Medical College and Hospital, Jhalawar, Rajasthan, India

Received: 22 October 2016

Accepted: 17 November 2016

\section{*Correspondence:}

Dr. Apurva Garg,

E-mail: apurvagarg89@gmail.com

Copyright: $\odot$ the author(s), publisher and licensee Medip Academy. This is an open-access article distributed under the terms of the Creative Commons Attribution Non-Commercial License, which permits unrestricted non-commercial use, distribution, and reproduction in any medium, provided the original work is properly cited.

\begin{abstract}
Background: The aim of this study was to compare the efficacy and safety of iron sucrose with oral iron in the treatment of iron deficiency anemia of pregnancy.

Methods: An interventional comparative study was conducted at Jhalawar Medical College, Jhalawar involving 80 pregnant women with iron deficiency anemia from March 2016 to August 2016. Inclusion criteria were gestational age between 24-32 weeks with established iron deficiency anemia, with hemoglobin between 7-10g/dl. Target Hemoglobin was $11 \mathrm{~g} / \mathrm{dl}$. In intravenous iron sucrose group iron sucrose dose was calculated from following formula: total iron dose required $(\mathrm{mg})=2.4 \mathrm{x}$ body weight in $\mathrm{Kg} \mathrm{x}$ (target $\mathrm{Hb}-$ Patient's $\mathrm{Hb} \mathrm{g} / \mathrm{dl})+500$. In oral iron, group patient received ferrous-sulphate $335 \mathrm{mg}$ daily $\mathrm{BD}$. Hb level were reviewed at 2, 4, 6 weeks.

Results: Change in Hemoglobin level from baseline significantly higher in IV iron group than oral iron group. In IV iron, group mean value of baseline $\mathrm{Hb}$ was $8.07 \pm 0.610 \mathrm{~g} / \mathrm{dl}$ and in oral iron group was $8.48 \pm 0.741 \mathrm{~g} / \mathrm{dl}$. At the end of 6-week mean hemoglobin in IV iron sucrose was $10.66 \pm 0.743 \mathrm{~g} / \mathrm{dl}$ and in oral iron group was $10.08 \pm 0.860 \mathrm{~g} / \mathrm{dl}$.

Conclusions: Intravenous iron sucrose elevates more $\mathrm{Hb}$ than oral iron, with less adverse effects.
\end{abstract}

Keywords: Hemoglobin, Iron sucrose, Iron deficiency anemia, Oral Ferrous Sulphate

\section{INTRODUCTION}

Anemia is a major public health problem worldwide. The global prevalence of anemia during pregnancy is estimated by World Health Organization to be $47.4 \%{ }^{1}$ According to recent WHO figures, India is included in the list of countries with high prevalence of anemia in pregnant women $(>40 \%){ }^{1}$ The prevalence of anemia among all age groups is high in India. Every second woman is anemic $(55 \%) .{ }^{2}$ Iron deficiency starts in childhood, worsens in adolescence and gets aggravated in pregnancy. The WHO defines anemia in pregnant women as hemoglobin level below $11 \mathrm{~g} / \mathrm{dl}$.

The Centers for Disease Control (CDC) recommends that hemoglobin in pregnant women should not be allowed to fall below $10.5 \mathrm{~g} / \mathrm{dl}$ in the second trimester, taking into account the physiological changes of pregnancy. ${ }^{3}$ The most common causes of anemia are poor nutrition, iron deficiency, malaria, hook worm infestation, HIV infection and hemoglobinopathies. ${ }^{4,5}$ Anemia is responsible for adverse obstetric outcome like cardiac failure, pre-eclampsia, antepartum hemorrhage, postpartum hemorrhage, puerperal sepsis, lactation failure, delayed wound healing. ${ }^{6}$ Anemia is a major cause of maternal mortality. Anemia accounts for $20 \%$ direct and $20 \%$ of indirect maternal deaths. ${ }^{7}$ Anemia leads to increased risk of blood transfusion during postpartum period. Iron therapy before delivery may reduce the transfusion rate for iron deficient women.

The aim of this study was to compare the efficacy and safety of iron sucrose with ferrous sulphate in treatment of iron deficiency anemia of pregnancy. 


\section{METHODS}

A interventional comparative study was conducted at OBG Dept. Jhalawar Medical College and hospital, Jhalawar from March 2016 - August 2016. All women attending antenatal clinic were screened for anemia between 24-32 weeks of gestation with sample size of 80 pregnant women.

Iron deficiency anemia was diagnosed on basis of peripheral blood film, complete blood count.

\section{Inclusion criteria}

- $\quad$ Singleton and uncomplicated pregnancy

- Gestational age between 24-32 weeks

- Hb between 7-10 g/dl

- Willing for enrolment in study

- $\quad$ Likely to come for follow up

\section{Exclusion criteria}

- Allergic to parenteral iron

- $\quad$ Patient with $\mathrm{Hb}<7 \mathrm{~g} / \mathrm{dl}>10 \mathrm{~g} / \mathrm{dl}$

- Patient with obstetrical complications

- Patient with acute and chronic infections

Ethical committee clearance was obtained. After taking consent, detailed history and examination of patient was done. Iron deficiency anemia was diagnosed. The women were divided into 2 groups.

Oral group: Oral iron Ferrous Sulphate $335 \mathrm{mg}$ containing $100 \mathrm{mg}$ of elemental iron BD was given to the patients for 4 weeks.

IV group: Parenteral iron sucrose was given to patients.

Oral group: Patients received Ferrous Sulphate $335 \mathrm{mg}$ containing $100 \mathrm{mg}$ elemental iron BD orally for 4 weeks. Patients were instructed to take the tablets with empty stomach and not to take coffee or tea after taking tablet. $\mathrm{Hb}$ was repeated at 2, 4 and 6 weeks after beginning of oral treatment.

Total iron dose was calculated by following formula:-

Body weight $(\mathrm{kg}) \times($ target $\mathrm{Hb}-$ pt's $\mathrm{Hb}) \mathrm{g} / \mathrm{dl}$ x $2.4+500$ $\mathrm{mg}$

Target $\mathrm{Hb}$ was $11 \mathrm{~g} / \mathrm{dl}$ and weight is patient's prepregnany weight in $\mathrm{Kg}$.

Calculated dose of iron sucrose was given in divided doses thrice weekly. $200 \mathrm{mg}$ of iron sucrose was mixed in $100 \mathrm{ml}$ of normal saline, the first few $\mathrm{ml}$ was infused intravenously over a period of $15 \mathrm{~min}$, if there was no adverse reaction remaining amount was infused over 30 min period. Oral iron was stopped during study. Patients were closely monitored for any adverse reaction and emergency drugs like steroid, antihistamines were kept ready. If there was any adverse reaction, drip was stopped immediately and treated accordingly. $\mathrm{Hb}$ was repeated after 2, 4, 6 weeks of beginning of iron therapy.

\section{At first visit:}

Detailed history, physical examination and obstetrics examination was done. Following investigations were done for each patient:

- $\mathrm{CBC}$

- Peripheral blood film

- Urine examination

All women were given 500 ug folic acid daily. Deworming was done with Albendazole $400 \mathrm{mg}$. Patients were advised to take high protein diet.

During follow up visit:

- Patients were enquired about adverse reaction.

- $\quad \mathrm{CBC}$ was repeated

\section{RESULTS}

Table 1: Distribution of $\mathrm{Hb}$ in different time in oral iron.

\begin{tabular}{|lllll|}
\hline $\begin{array}{l}\text { Hb } \\
(\mathrm{g} / \mathrm{dl})\end{array}$ & $\begin{array}{c}\text { Mean } \\
(\mathrm{g} / \mathrm{dll})\end{array}$ & $\begin{array}{l}\text { Std. } \\
\text { dev. }\end{array}$ & $\begin{array}{l}\text { F } \\
\text { value }\end{array}$ & P value \\
\hline Base line $\mathrm{Hb}$ & 8.4833 & 0.7418 & & \\
\hline 2nd week $\mathrm{Hb}$ & 8.7333 & 0.7396 & 23.743 & $<0.0001^{*}$ \\
\hline 4th week $\mathrm{Hb}$ & 9.2033 & 0.825 & & \\
\hline 6th week $\mathrm{Hb}$ & 10.0867 & 0.8609 & & \\
\hline
\end{tabular}

Table 2: Distribution of $\mathrm{Hb}$ in different time in IV iron.

\begin{tabular}{|lclll|}
\hline $\begin{array}{l}\text { Hb } \\
(\mathrm{g} / \mathrm{dl})\end{array}$ & $\begin{array}{c}\text { Mean } \\
(\mathrm{g} / \mathrm{dl})\end{array}$ & $\begin{array}{l}\text { Std. } \\
\text { dev. }\end{array}$ & F value & P value \\
\hline Base line $\mathrm{Hb}$ & 8.0767 & 0.6100 & & \\
\hline 2nd week $\mathrm{Hb}$ & 8.8167 & 0.6164 & 82.351 & $<0.0001^{*}$ \\
\hline 4th week $\mathrm{Hb}$ & 9.7900 & 0.7406 & & \\
\hline 6th week $\mathrm{Hb}$ & 10.660 & 0.7430 & & \\
\hline
\end{tabular}

80 women were included in the study. At the end of study, we had complete data of 60 patients (30 in each group). 12 patient dropped out from oral iron group and 8 patients dropped out from IV iron group.

Initial demographic and clinical characteristic were similar in both groups. In oral group mean baseline $\mathrm{Hb}$ was $8.48 \pm 0.741 \mathrm{~g} / \mathrm{dl}$ and in IV group mean baseline $\mathrm{Hb}$ was $8.07 \pm 0.610 \mathrm{~g} / \mathrm{dl}$. An increase in $\mathrm{Hb}$ was observed from baseline to 6 weeks in each group, but the increase in IV group is more than oral group. 
Mean $\mathrm{Hb}$ was $8.733 \pm 0.739 \mathrm{~g} / \mathrm{dl}$ at 2 weeks, $9.20 \pm 0.825$ $\mathrm{g} / \mathrm{dl}$ at 4 weeks, $10.08 \pm .860 \mathrm{~g} / \mathrm{dl}$ at 6 weeks compared to IV iron which was $8.81 \pm 0.616 \mathrm{~g} / \mathrm{dl}$ at 2 weeks, $9.79 \pm 0.740 \mathrm{~g} / \mathrm{dl}$ at 4 weeks, $10.66 \pm 0.743 \mathrm{~g} / \mathrm{dl}$ at 6 weeks. There is a significant variation $(\mathrm{p}<0.005)$ in $\mathrm{Hb}$ in different times in oral and IV iron groups but according to mean $\mathrm{Hb}$ levels were increased in succeed time. Rise of mean $\mathrm{Hb}$ from baseline to 6 weeks in oral group is 1.6 $\mathrm{g} / \mathrm{dl}$ where is in IV group it is $2.59 \mathrm{~g} / \mathrm{dl}$. Target $\mathrm{Hb}$ achieved by patients in oral iron group was $16.66 \%$ while in IV iron group was $36.66 \%$.

Table 3: Comparison of $\mathrm{Hb}$ in IV and Oral Iron in different time period.

\begin{tabular}{|llllcc|}
\hline $\begin{array}{l}\mathrm{H} \text { (b } \\
(\mathrm{g} / \mathrm{dll})\end{array}$ & Group & $\begin{array}{c}\text { Mean } \\
\text { (g/dl) }\end{array}$ & $\begin{array}{l}\text { Std. } \\
\text { dev. }\end{array}$ & T value & P value \\
\hline Base line $\mathrm{Hb}$ & IV iron & 8.0767 & 0.61008 & 1.7483 & 0.0857 \\
\hline & Oral iron & 8.4833 & 0.74189 & & \\
\hline 2nd week Hb & IV iron & 8.8167 & 0.61649 & 0.474 & 0.637 \\
\hline & Oral iron & 8.7333 & 0.73968 & & $0.005^{*}$ \\
\hline 4th week Hb & IV iron & 9.7900 & 0.74062 & 2.897 & $0.008^{*}$ \\
\hline & Oral iron & 9.2033 & 0.82566 & & \\
\hline 6th week $\mathrm{Hb}$ & IV iron & 10.6600 & 0.74306 & 2.761 & \\
\hline & Oral iron & 10.0867 & 0.86093 & & \\
\hline
\end{tabular}

Table 4: Adverse reactions with oral and IV iron.

\begin{tabular}{|lll|}
\hline Symptoms & Oral iron & IV iron \\
\hline Nausea, vomiting & 8 & 0 \\
\hline Constipation & 6 & 0 \\
\hline Fever/chills & 0 & 1 \\
\hline Rashes & 0 & 0 \\
\hline Dizziness & 0 & 3 \\
\hline Thrombophlebitis & 0 & 1 \\
\hline Total & 14 & 5 \\
\hline
\end{tabular}

There is no significant difference in $\mathrm{Hb}$ level between iron sucrose and oral iron group $(\mathrm{p}>0.05)$ in baseline and 2nd week. But found significant difference in 4th and 6th week $(\mathrm{p}<0.005)$ (Table 3).

In oral iron group $46.66 \%$ show adverse reaction while in IV group $16.66 \%$ show adverse reaction. None major anaphylactic reaction noted with iron sucrose.

\section{DISCUSSION}

Iron deficiency anemia is a major public health problem worldwide. Increased requirements aggravate IDA during pregnancy. There is a great demand for iron to meet the requirement of red blood cell mass expansion in the mother, fetal and placental blood and blood loss at delivery. ${ }^{8,9}$ This is aggravated by poor absorption of iron due to pregnancy induced nausea, vomiting, motility disorder with indigestion and phytate rich Indian diet. ${ }^{8,9}$ Other factors responsible for high incidence of IDA in India include early marriage, teenage pregnancy, multiple pregnancies, less birth spacing, low iron and folic acid intake and high incidence of hookworm infestation in Indian population. ${ }^{10}$
In view of high prevalence of anemia in pregnancy and serious adverse consequence in both mother and baby, management of anemia in pregnancy was accorded a very high priority. There are various forms of treatment for IDA. Over the past years, various oral, intramuscular and intravenous preparations of iron have been used for correction of IDA in the pregnant patients. ${ }^{11-13}$

The study confirmed that parenteral administered iron sucrose elevated hemoglobin more than oral iron.

Al Momenet $\mathrm{al}^{13}$, in their study compared 52 women treated with intravenous iron sucrose and 59 women treated with $300 \mathrm{mg}$ oral iron sulfate. Intravenous iron sucrose complex achieved significantly higher hemoglobin levels $128.5 \pm 6.6$ versus $111.4 \pm 12.4 \mathrm{~g} / \mathrm{l}$ in the oral iron group $(\mathrm{p}<0.001)$ in a shorter period $6.9 \pm 1.8$ versus $14.9 \pm 3.1$ weeks in control group $(p \leq 0.001)$. Iron sucrose complex showed no major side effects while 4 $(6 \%)$ of the ferrous sulphate could not tolerate ferrous sulphate, $30 \%$ complained of gastro intestinal symptoms. These results are similar to our study.

Deeba $\mathrm{S}$ et $\mathrm{al}^{14}$, in their study concluded that difference in $\mathrm{Hb}$ from baseline in IV group was $1.72 \pm 0.484$ at 2 weeks, $2.18 \pm 0.865$ at 4 weeks, $2.89 \pm 0.5989$ at 6 weeks compared to oral iron, which was $0.5550 \pm 0.456$ at 2 weeks, $1.39 \pm 0.4402$ at 4 weeks, and $1.9 \pm 0.3020$ at 6 weeks. $P$ value was 0.000 which was clinically significant and showed that $\mathrm{Hb}$ levels were increased more in intravenous group. These results are similar to our study.

\section{CONCLUSION}

In view of the failure of oral iron in the correction of anemia to significant extent in pregnant women with 
moderate anemia intravenous administration of iron under supervision is a better alternative for women with moderate anemia. To conclude, intravenous administration of iron sucrose is safe, highly efficacious with better compliance for the treatment of iron deficiency anemia. Iron sucrose therapy is more effective in achieving the optimum results because of better compliance, better absorption.

Funding: No funding sources

Conflict of interest: None declared

Ethical approval: The study was approved by the Institutional Ethics Committee

\section{REFERENCES}

1. De benoist B. (eds). Worldwide Prevalance of anemia 19993-2005. WHO Global Database on Anemia Geneva, World Health Organization, 2008.

2. Addressing India's Nutrition Challenges. Report of the Multistake holder Retreat. Planning Commission, Government of India. 2011.

3. Center for Disease Control and Prevention. CDC criteria for anemia in children and childbearing-aged women .Morb Moral Wkly Rep. 1989;38:400.

4. Candio F, Hofmeyr GJ. Treatments for iron deficiency anemia in pregnancy. RHL commentary. The WHO Reproductive Health Library. Geneva: World Health Organization; 2007.

5. UNICEF/UNO/WHO. Iron deficiency anemia: World Health Organization; 2001.

6. Ian Donald's practical obstetric problems, seventh edition, 2014:198.
7. Maternal Mortality in India 1997-2003, Registrar General of India. Available from: http://www.censusindia.net/. Accessed on December $15,2008$.

8. Breyman C. Iron deficiency and anemia in pregnancy: Modern aspects of diagnosis and therapy. Blood Cells Mol Dis. 2002;29:506-16.

9. Breymann $\mathrm{C}$; Anemia working group. Current aspects of diagnosis and therapy of iron deficiency anemia in pregnancy. Schweiz Rundsch Med Prax. 2001;90:1283-91.

10. Toteja GS, Singh P. Micronutrient profile of Indian Population. New Delhi: Indian Council of Medical Research; 2004.

11. Bayoumeu F, Subiran-Buisset C, Baka NE, Legagneur H, Monnier-Barbarino P, Lax-enaire MC. Iron therapy in iron deficiency nemia in pregnancy: Intravenous route versus oral route. Am J Obstet Gynecol. 2002;186:518-22.

12. Perewusny KG, Huck R, Huck A, Brey-mann C. Parenteral iron-sucrose complex. $\mathrm{Br} \mathrm{J}$ Nutr. 2002;88:3-10.

13. Al-Momen AK, al-Meshari A, al-Nuaim L, Saddique A, Abutalib Z, Khashogi T, et al. Intravenous iron sucrose complex in the treatment of iron deficiency anemia during pregnancy. Eur J Obstet Gynecol Reprod Biol. 1996;69:121-4.

14. Deeba S, Purandare Shekhar V, Sathe AV. Iron deficiency anemia in pregnancy: Intravenus verus oral route. Journal of Obstetrics and Gynecology of India. 2012;62(3):317-321.

Cite this article as: Garg A, Agarwal M, Shankar U, Shetty S. Comparative study of oral iron and intravenous iron sucrose for the treatment of iron deficiency anemia in pregnancy. Int $\mathbf{J}$ Reprod Contracept Obstet Gynecol 2017;6:172-5. 